\title{
FREE SEX BEHAVIORAL FACTORS BASED ON THE HEALTH BELIEF MODEL: A STUDY IN TEENAGERS IN MUNA, INDONESIA
}

Tasnim Tasnim ${ }^{1}$ *, Abdul Sila ${ }^{2}$, Rahmat Sofyan Patadjai ${ }^{3}$, Sunarsih ${ }^{4}$, La Ode Saafi $^{5}$, Muhammad Idrus $^{6}$, Putu Suri Saraswati ${ }^{7}$

1,2,4,5,6,7 College of Health Sciences Mandala Waluya Kendari, Jl.AH Nasution No. G-37 Kambu, Kendari, Indonesia ${ }^{3}$ Haluoleo University, Kendari, Indonesia

* Correspondence

Tasnim Tasnim

College of Health Sciences Mandala Waluya Kendari

Jl. Jend. AH. Nasution, Kambu, Kendari, Southeast Sulawesi

E-mail: tasnim349@gmail.com, Phone: +6282237658472

\begin{abstract}
Background: Free sex behavior in Indonesian teen has vastly improved. Free sex issues is the concern for all. The aim of this research was to determine the factors of free sex behavioral based on the health belief model.

Methods:This research was a cross sectional study. The population were 304 students and sample of 75 respondents, the sampling using simple random sampling technique.

Results: The results showed that there is correlation between vulnerability/seriousness perception to free sex behavior, with Chi Square $9.182(\varphi=0350)$. There is a correlation between the level of threat perception to free sex behavior with Chi Square 14.815 ( $\varphi=$ 0.444). There is a correlation between religiosity to free sex behavior with Chi Square $23.628(\varphi=0561)$. There is a relationship between the gender to free sex behavior with Chi Square 16,000 $(\varphi=0462)$. There is a correlation between social media to free sex behavior with Chi Square 25,000 $(\varphi=0.577)$.

Conclusion: Factors affecting free sex behavior are perception of the level of vulnerability / seriousness and threat of disease due to sex, religiosity, gender and social media. We are expected to SMAN I Pasir Putih to be able in using this research as information and consideration in developing the knowledge of adolescents about the dangers of free sex behavior.
\end{abstract}

Keywords: Free Sex, Behavior, Teenager 


\section{INTRODUCTION}

Indonesian teen free sex behavior improved greatly where Ind Police Watch (IPW) explain problem-free sex among teenagers Indonesia is very worrying (1). Throughout 2017 there were 178 new baby was born in the waste on the streets (2). This number rose to 90 cases on appeal in 2016. A survey of adolescent reproductive health in Indonesia, that were first dating at the age of 12 years (3). Data from Southeast Sulawesi BKKBN, the age of first started going out on average at the age of 15 years (4).

The opposite sex with a sex drive kodratif things experienced by teenagers(5). At this stage the role of the parents and the teachers are very influential to provide an understanding of the meanings of sexuality in adolescents according to prevailing moral values in society(6). In times of change is what makes adolescents experiencing a crisis. Free sex as one of the deviant behavior of teenagers. When it appears the fact that $74.89 \%$ of adolescents in Kupang, Cirebon, Palembang, Singkawang and Tasik Malaya sex with their boyfriends(7). Adolescents begin to blame, accused of immodest, immoral, degenerate not even to say no religion. Teens do it because they do not get reproductive health education, so do not know the danger or the impact of free sex (8).

In Muna, especially in SMAN 1 Pasir Putih, the level of free sex behavior is not foreign to occur among adolescents. It can be stated based on the level of events that often occur from year to year, one of which is the problem of early marriage that often afflicts children teenager. This happens because it is caused by several factors, including the factor of promiscuity that often occurs in young children that affect the behavior of free sex. The purpose of this study to determine the factors associated with adolescent free sex behavior in terms of the Health Belief Model in SMAN I Pasir Putih. 


\section{METHOD}

This study was a cross sectional study (9). The population of this research is the students of SMAN 1 Pasir Putih grade 1 to 3 with a total 304 students. The sample in this study of 75 samples, using Simple Random Sampling (10). The dependent variable is perilaku free sex teen while independent variables namely perception adolescents, gender, religiosity, and social media. Instrument research used questionnaires were then analyzed using statistical test Chi Square.

\section{RESULTS}

Table 1 shows that respondents who have an understanding of the vulnerability and the seriousness of the disease due to the behavior of free sex amounted to 34 people while the category of respondents who do not understand amounted to 41 respondents. Results of analysis using Chi Square test values obtained X2 count 9.182> 3.481 X2 table which means that these variables have a relationship with a weak category, where the value of $\varphi=0.350$. Table 2 shows that respondents who have an understanding of the level of the threat of diseases caused by free sex behaviors were 30 respondents while the category of respondents who do not understand are 45 respondents. Based on the analysis using Chi Square test 14.815 X2 count> X2 table artiya 3.481 which these variables had affairs with the middle category, where the value of $\varphi=0.444$. The results showed that in Table 3 respondents who have a sufficient understanding of religion amounts to 32 respondents while the category of respondents who have less understanding of religion amounts to 43 respondents. Chi Square test 23.628 X2 count> X2 table 3.481 which means that these variables have a relationship with the medium category, where the value of $\varphi=0.561$. 
Table 4 shows that the respondents were male gender was 25 respondents, whereas female sex jenias category amounted to 50 respondents. Based on the analysis using Chi Square test X2 count 16,000> X2 table 3.481 which means that these variables have a relationship with the medium category, where the value of $\varphi=0,462$. Table 5 indicates that respondents with social media support sufficient amounts to 50 respondents, while respondents with less social media support amounted to 25 respondents. Chi Square test X2 count 25,000> X2 table 3.481 which means that these variables have a relationship with the medium category in which the value of $\varphi=0.577$.

Table 1

Correlation Between Vulnerability / Seriousness Perception to Free Sex Behavior in SMAN I Pasir Putih Muna

\begin{tabular}{|c|c|c|c|c|c|c|c|c|}
\hline \multirow{3}{*}{ No. } & \multirow{3}{*}{$\begin{array}{l}\text { Vulnerability / } \\
\text { seriousness }\end{array}$} & \multicolumn{4}{|c|}{ Free sex behavior } & \multirow{3}{*}{ Total } & \multirow{3}{*}{$\%$} & \multirow{3}{*}{ Statistical } \\
\hline & & \multicolumn{2}{|c|}{ Understand } & \multicolumn{2}{|c|}{ No } & & & \\
\hline & & $\mathbf{n}$ & $\%$ & $\mathbf{n}$ & $\%$ & & & \\
\hline 1 & Understand & 14 & 41.2 & 20 & 58.8 & 34 & 100 & $\mathrm{X}_{\text {count }}^{2}=9.182$ \\
\hline 2 & No & 31 & 75.6 & 10 & 24.4 & 41 & 100 & $\mathrm{X}^{2}$ table $=3.481$ \\
\hline & Total & 45 & 60.0 & 30 & 40.0 & 75 & 100 & $\varphi=0.350$ \\
\hline
\end{tabular}

Table 2

Correlation Between the Threat Perception to Free Sex Behavior in SMAN I Pasir Putih Muna

\begin{tabular}{|c|c|c|c|c|c|c|c|c|}
\hline \multirow{3}{*}{ No. } & \multirow{3}{*}{ Threat } & \multicolumn{4}{|c|}{ Free sex behavior } & \multirow{3}{*}{ Total } & \multirow{3}{*}{$\%$} & \multirow{3}{*}{ Statistical } \\
\hline & & \multicolumn{2}{|c|}{ Understand } & \multicolumn{2}{|c|}{ No } & & & \\
\hline & & $\mathbf{n}$ & $\%$ & n & $\%$ & & & \\
\hline 1 & Understand & 10 & 33.3 & 20 & 66.7 & 30 & 100 & $X_{\text {count }}^{2}=14.815$ \\
\hline 2 & No & 35 & 77.8 & 10 & 22.2 & 45 & 100 & $\mathrm{X}^{2}$ table $=3.481$ \\
\hline & Total & 45 & 60.0 & 30 & 40.0 & 75 & 100 & $\varphi=0.444$ \\
\hline
\end{tabular}

Table 3

Correlation Between Religiosity to Free Sex Behavior SMAN I Pasir Putih Muna

\begin{tabular}{|c|c|c|c|c|c|c|c|c|}
\hline \multirow{3}{*}{ No. } & \multirow{3}{*}{ Religiosity } & \multicolumn{4}{|c|}{ Free sex behavior } & \multirow{3}{*}{ Total } & \multirow{3}{*}{$\%$} & \multirow{3}{*}{ Statistical } \\
\hline & & \multicolumn{2}{|c|}{ Understand } & \multicolumn{2}{|c|}{ No } & & & \\
\hline & & $\mathbf{n}$ & $\%$ & n & $\%$ & & & \\
\hline 1 & Enough & 9 & 28.1 & 23 & 71.9 & 32 & 100 & $X_{\text {count }}^{2}=23.628$ \\
\hline 2 & Less & 36 & 83.7 & 7 & 16.3 & 43 & 100 & $\mathrm{X}^{2}$ table $=3.481$ \\
\hline & Total & 45 & 60.0 & 30 & 40.0 & 75 & 100 & $\varphi=0561$ \\
\hline
\end{tabular}


Table 4

Correlation Between Gender to Free Sex Behavior in SMAN I White sand Muna

\begin{tabular}{|c|c|c|c|c|c|c|c|c|}
\hline \multirow{3}{*}{ No. } & \multirow{3}{*}{ Gender } & \multicolumn{4}{|c|}{ Free sex behavior } & \multirow{3}{*}{ Total } & \multirow{3}{*}{$\%$} & \multirow{3}{*}{ Statistical } \\
\hline & & \multicolumn{2}{|c|}{ Understand } & \multicolumn{2}{|c|}{ No } & & & \\
\hline & & $\mathbf{n}$ & $\%$ & $\mathbf{n}$ & $\%$ & & & \\
\hline 1 & Man & 23 & 92.2 & 2 & 8.0 & 25 & 100 & $X_{\text {count }}^{2}=16,000$ \\
\hline 2 & Woman & 22 & 44.0 & 28 & 56.0 & 50 & 100 & $\mathrm{X}^{2}$ table $=3.481$ \\
\hline & Total & 45 & 60.0 & 30 & 40.0 & 75 & 100 & $\varphi=0462$ \\
\hline
\end{tabular}

Table 5

Correlation Between Social Media to Free Sex Behavior SMAN I Pasir Putih Muna

\begin{tabular}{|c|c|c|c|c|c|c|c|c|}
\hline \multirow{3}{*}{ No. } & \multirow{3}{*}{$\begin{array}{l}\text { Social } \\
\text { media }\end{array}$} & \multicolumn{4}{|c|}{ Free sex behavior } & \multirow{3}{*}{ Total } & \multirow{3}{*}{$\%$} & \multirow{3}{*}{ Statistical } \\
\hline & & \multicolumn{2}{|c|}{ Understand } & \multicolumn{2}{|c|}{ No } & & & \\
\hline & & $\mathbf{n}$ & $\%$ & $\mathbf{n}$ & $\%$ & & & \\
\hline 1 & Often & 40 & 80.0 & 10 & 20.0 & 50 & 100 & \multirow{3}{*}{$\begin{array}{l}X_{\text {count }}^{2}=25,000 \\
X^{2} \text { table }=3.481 \\
\varphi=0.577\end{array}$} \\
\hline \multirow[t]{2}{*}{2} & Rarely & 5 & 20.0 & 20 & 80.0 & 25 & 100 & \\
\hline & Total & 45 & 60.0 & 30 & 40.0 & 75 & 100 & \\
\hline
\end{tabular}

\section{DISCUSSIONS}

Correlation Between Vulnerability / Seriousness Perception to Free Sex Behavior in SMAN I Pasir Putih Muna

From the results of research conducted in SMAN 1 Pasir Putih Muna, with the number of respondents as many as 75 respondents, that has an understanding of the vulnerability and the seriousness of the disease behavior, free sex amounted to 34 respondents, while respondents who do not understand amounted to 41 respondents.

Adolescent understanding about the vulnerability / seriousness of the diseasefree sex is motivated by curiosity level adolescents about the dangers or the impact of free sex as well as learn from the experiences that occur around their environment (11). While the lack of understanding about the vulnerability of adolescent / seriousness of the disease as a result of casual sex, caused by a lack of information obtained by teenagers both in the family, school, and health workers. 
Therefore, early sex education should be implemented with the expectation that teenagers can find out about the effects or dangers of free sex, so that their health can be maintained especially reprodiksinya health (12). Parents also should be able to accompany their children melaluai adolescence so that the child is not easy to follow the negative influence of the environment.

\section{Correlation Between the Threat Perception to Free Sex Behavior in SMAN I Pasir}

\section{Putih Muna}

Sex behavior is not a new thing occur among adolescents when this sekarng. Day by day, the phenomenon of the free sex behavior instead of diminishing, but rather worsened-so (13). Free sex behavior among adolescents has reached a point of concern are quite severe (14) (15).

In SMAN I Pasir Putih, adolescent knowledge level about the threat of free sex behavior is good enough. It can be seen from the results of filling the questionnaire students consisting of 75 respondents, where 42 respondents are already quite familiar to the impact of the threat of disease-free sex behavior itself, while 33 respondents are still less understood.

Teenagers good understanding about the threat of diseases caused by free sex are not guarantees of teens not do casual sex behavior, where the results of these studies that teens who understand the threat of disease due to sex, there was a small fraction of those who know about the behavior of -prilaku free sex itself. While respondents do not have an understanding of the threat of disease from casual sex, most of them fully aware of the behaviors of free sex itself. 


\section{Correlation Between Religiosity to Free Sex Behavior in SMAN I Pasir Putih Muna}

Religiosity is the spiritual attitude (personal) every human being before God were a bit much a mystery to others, which includes the totality of the human person. As the inner attitudes, religiosity can not be seen directly, but can be seen from the implementation of religiosity behavior itself (16).

Based on the results of research conducted in SMAN 1 Pasir Putih Muna, from data analysis, found that respondents who have sufficient understanding of religion amounts to 32 respondents, while the category of respondents who have less understanding of religion amounts to 43 respondents.

The level of understanding a good teen religiosity caused by factors upbringing and parental control to teenagers (17). While the lack of understanding about the religiosity of adolescents due to lack of parents of adolescents, as well as the influences of the environment, as well as the lack of religious activities of the existing environment (18).

It can be concluded that the higher the religiosity owned a teenager, the lower adolescent sex behavior that appears, vice versa the lower religiosity owned a teenager, the higher the adolescent sex behavior that appears.

\section{Correlation Between Gender to Free Sex Behavior in SMAN I White sand Muna}

In sexual behavior, there is a difference between the genders male and female. This difference is caused by biological factors, and social. Biologically men are more easily aroused and erections and orgasms than women. Socially males tend to be more 
free than women. In relations with the opposite sex, men -laki tend to be aggressive while women tend to be more passive (19).

From the results of the analysis showed that men with the number of respondents 25 people more likely to have casual sex behavior compared to women with the number of respondents as many as 50 people. Thus, it can be stated that gender related and significant influence on the behavior of free sex teen. Socially, the social norm in women is more binding. Women are also expected to behave in a soft, smooth and stay a virgin before marriage. While the men are freer socially, aggressive behavior and come home at night for example is regarded as commonplace.

The results are consistent with the results of research and Mualfiah (2014) found that in sexual behavior, adolescent girls are required to be passive, especially in the sexual interaction. Instead young men are active in sexual interaction that acts as an initiator in the sexual interaction (20).

\section{Correlation Between Social Media to Free Sex Behavior in SMAN I Pasir Putih}

\section{Muna}

In the development of many presenting internet services to facilitate users in obtaining resources, one satunnya is social media. Currently social media is used not only to share information but also as a base to create a virtual friendship denagan share profiles with photos, videos, ideas and so forth (21).

Based on existing research results can be seen that the respondents with the support of sufficient social media amounted to 50 respondents, while respondents with less social media support amounted to 25 respondents. In accordance with the above description, one of the factors that influence adolescents in making free sex behavior is social media. The statement can be strengthened by the results of previously conducted 
studies (22) stated that social media has the potential to stimulate other social media users to replicate and distribute their sexual behavior in social media. Meanwhile, according to Paramitha (2018) about the effects of the use of social media to free sex teen behavior, stating there is a relationship of social media with sexual behavior in adolescents, where teens are using (23).

\section{CONCLUSION}

Lack of understanding about the vulnerability of adolescent Perception / seriousness and threats of a disease caused by promiscuity, lack of religiosity youth, gender factor and abuse of social media are all factors that lead teenagers to do free sex behavior. Thereforeit is expected that the relevant institutions so that these results can be used as input for the development of science in studying the behavior of free sex so that education can be used as educator for youth as a form of awareness and prevention against free sex behavior.

\section{REFERENCES}

1. Moran LJ. Sexuality and victimisation. Handbook of Victims and Victimology. 2017:156-73.

2. Westra L. Child Law in the International Context: Exploitation, Abuse and the Limits of Labour Laws. Child Law: Springer; 2014. p. 95-125.

3. Hamdan M. Chemical Castration Penalty for Sex Offenders in Indonesia. The Social Sciences. 2017;12(11):2040-3.

4. Andriani H, Yasnani Y. Hubungan Pengetahuan, Akses Media Informasi Dan Peran Keluarga Terhadap Perilaku Seksual Pada Siswa Smk Negeri 1 Kendari Tahun 2016. Jurnal Ilmiah Mahasiswa Kesehatan Masyarakat. 2017;1(3).

5. Soebijanto N, Waspadji S. Adiponectin levels and its role in insulin resistance among adult women with metabolic syndrome. Age (years). 2010;30(40):41-50.

6. Rosdarni R, Dasuki D, Waluyo SD. Pengaruh Faktor Personal Berpengaruh Terhadap Perilaku Seksual Pranikah pada Remaja di Kota Kendari Provinsi Sulawesi Tenggara. Kesmas: National Public Health Journal. 2015;9(3):214-21. 
7. Oktarina E, Fajar NA, Budi IS. The Influence of Hard Skill and Soft Skill Factors with Sexual Behavior in Adolescent at Seberang Ilir Area of Palembang City on 2011. Jurnal Ilmu Kesehatan Masyarakat. 2012;3(1):81-9.

8. Senjaya S. Free Sex Behavior In Teenage Sma Negri 2 Leles Garut. Jurnal Kesehatan Bakti Tunas Husada: Jurnal Ilmu-ilmu Keperawatan, Analis Kesehatan dan Farmasi. 2018;18(2).

9. Ismail HF. Statistika Untuk Penelitian Pendidikan dan Ilmu-Ilmu Sosial: Kencana; 2018.

10. Lemeshow S, Hosmer DW, Klar J, Lwanga SK. Besar sampel dalam penelitian kesehatan. Yogyakarta: Gajah Mada University. 1997.

11. Februanti S. Gambaran Pengetahuan Remaja Tentang Dampak Seks Pranikah Di Salah Satu Sma Kota Tasikmalaya. Jurnal Kesehatan Bakti Tunas Husada: Jurnal Ilmu-ilmu Keperawatan, Analis Kesehatan dan Farmasi. 2018;17(2):261-7.

12. Tri N, Muhartati M. Pengaruh Pendidikan Seks Terhadap Tingkat Pengetahuan Dan Sikap Remaja Dalam Pencegahan Seks Pranikah Di Smk N 2 Sewon Bantul Yogyakarta: STIKES'Aisyiyah Yogyakarta; 2014.

13. Unayah N, Sabarisman M. Fenomena kenakalan remaja dan kriminalitas. Sosio informa. 2016;1(2).

14. Reichert T, Lambiase J. Sex in advertising: Perspectives on the erotic appeal: Routledge; 2014.

15. Almurhan A, Amperaningsih Y. Fenomena Perilaku Seks Remaja SMP Di Kecamatan Punggur Kabupaten Lampung Tengah. Jurnal Ilmiah Keperawatan Sai Betik. 2016;8(1):72-81.

16. Khairunnisa A. Hubungan religiusitas dan kontrol diri dengan perilaku seksual pranikah remaja di MAN 1 Samarinda. Ejournal psikologi. 2013;1(2):220-9.

17. Muslichah M, Hilman O. Pengaruh Hubungan Orang Tua dan Anak Remaja terhadap Pengetahuan Sikap Perilaku tentang Seks Bebas dan Narkoba. Mutiara Medika: Jurnal Kedokteran dan Kesehatan. 2016;8(2 (s)):83-8.

18. Hidayat K. Pengaruh Harga Diri dan Penalaran Moral terhadap Perilaku Seksual Remaja Berpacaran di SMK Negeri 5 Samarinda. Jurnal Psikologi. 2013;1(1):80-7.

19. Suharsimi A. Dasar-dasar evaluasi pendidikan. Jakarta: Bumi Aksara. 2009.

20. Mualfiah $R$, Indrijati $H$. Hubungan Antara Tingkat Harga Diri dengan Kecenderungan Perilaku Seks Pranikah pada Remaja Pondok Pesantren Assalafi Alfitrah Surabaya. Jurnal Psikologi Klinis dan Kesehatan Mental. 2014;3(03):159.

21. Nasrullah R, Si M. Teori dan riset media siber (cybermedia): Kencana; 2016.

22. Landripet I, Buško V, Štulhofer A. Testing the content progression thesis: a longitudinal assessment of pornography use and preference for coercive and violent content among male adolescents. Social science research. 2019;81:32-41.

23. Paramitha D, Ismahmudi R. Hubungan antara Penggunaan Media Sosial dengan Tingkat Pengetahuan Seksual Remaja di SMAN 5 Samarinda. 2018. 